\title{
IMPLEMENTASI TEKNOLOGI 3D AUGMENTED REALITY UNTUK PEMETAAN KAMPUS UNISKA MAB
}

\author{
Indra Setiawan ${ }^{1}$, Nadiya Hijriana ${ }^{2}$ \\ Program Studi Teknik Informatika, Fakultas Teknologi Informasi \\ Universitas Islam Kalimantan Muhammad Aryad Al Banjari Banjarmasin \\ E-mail: ${ }^{1}$ indra.ftiuniska15@gmail.com, ${ }^{2}$ nadyahijriana@yahoo.com
}

\begin{abstract}
ABSTRAK
Universitas Islam Kalimantan Muhammad Arsyad Al Banjari Banjarmasin atau UNISKA MAB adalah salah satu perguruan tinggi swasta yang cukup banyak diminati oleh masyarakat di Kalimantan. Untuk kegiatan promosi maupun pengenalan kampus, UNISKA MAB masih memakai cara lama seperti lewat spanduk (baliho), media cetak maupun lewat informasi secara online di website resmi UNISKA MAB. Sedangkan untuk mahasiswa baru, informasi tentang kampus secara detail dirasakan masih kurang walaupun pada kegiatan Pengenalan Kehidupan Kampus Mahasiswa Baru (PKKMB), mahasiswa baru memperoleh buku pedoman tentang kampus UNISKA MAB, namun dirasakan masih kurang efektif. Hal ini dibuktikan dengan masih adanya mahasiswa baru yang kebingungan mencari lokasi ruang perkuliahan, ruang BAK atau ruangan lainnya.

Berdasarkan permasalahan tersebut, maka dibuatlah sebuah aplikasi berbasis android dengan menggunakan teknologi AR (Augmented Reality). Dengan adanya aplikasi ini, pengguna terutama mahasiswa baru dapat mengetahui lebih detail tentang lokasi atau ruangan-ruangan yang ada di kampus UNISKA MAB melalui smartphone yang mereka miliki. Selain itu aplikasi yang dilengkapi fitur visual 3D dan audio ini dapat menjadi salah satu alternatif tambahan dalam kegiatan promosi tentang UNISKA ke sekolah-sekolah yang ada di Kalimantan.
\end{abstract}

Kata Kunci : UNISKA, Android, Aplikasi, Augmented Reality

\section{PENDAHULUAN}

Universitas Islam Kalimantan (UNISKA) Muhammad Arsyad Al Banjari adalah perguruan tinggi swasta tertua dan terbesar di Kalimantan Selatan, perguruan tinggi ini cukup dikenal di Kalimantan sehingga dari tahun ke tahun peminatnya bertambah, hingga sekarang jumlah mahasiswanya berjumlah sekitar 17.000 orang, dan juga kampus pusat UNISKA yang berlokasi di jalan Adhiyaksa Nomor 2 Kayu Tangi Banjarmasin ini terbilang tidak terlalu luas. Sehingga dalam beberapa tahun ke depan UNISKA membangun kampus baru yang representatif di jalan Trans Kalimantan, Kabupaten Barito Kuala.

Dalam hal pengenalan kampus UNISKA masih menggunakan cara yang umum seperti melalui website dan media cetak maupun lewat spanduk (baliho). Buku pedoman yang diberikan kepada mahasiswa pada saat PKKMB juga jarang dibaca oleh mahasiswa itu sendiri, dan pengenalan gedung baru UNISKA menggunakan miniatur 3D dengan memanfaatkan sterofoam dimana miniatur ini menjadi pajangan di lobi UNISKA. Namun miniatur 3D tersebut memiliki beberapa kelemahan, yaitu tidak praktis dari segi ukuran, karena membutuhkan ruang yang besar, hanya dapat dilihat oleh orang mengunjungi UNISKA, dan dari segi pemanfaatan teknologi terlihat kurang mengikuti perkembangan teknologi. Oleh karena itu dibutuhkan sebuah teknologi yang dapat mengabadikan bentuk-bentuk gedung baru UNISKA dalam suatu media yang tidak membutuhkan ruang menyimpan yang besar, praktis, canggih, dan menarik.

Suatu organisasi atau lembaga pendidikan dewasa ini menganggap bahwa promosi merupakan bagian penting dari pemasaran, karena pihak lembaga pendidikan berharap dengan promosi yang dilaksanakan secara efektif dapat bersaing dengan lembaga lain yang menghasilkan lulusan atau memberi jasa yang sejenis. Dengan pandangan demikian kegiatan promosi secara berkesinambungan dan terarah akan mampu mencapai hasil yang maksimal. Sayangnya perkembangan pembangunan di UNISKA tidak diikuti dengan perkembangan media promosinya, karena masih kurang adanya media promosi menggunakan teknologi yang terbaru.

Berkembangnya teknologi berbasis aplikasi, terutama di bidang sistem operasi Android serta IOS, membuat strategi promosi dapat dilakukan lebih aktraktif serta dapat dibuat lebih interaktif bagi penggunanya. Salah satu teknologi yang sedang popular di kalangan masyarakat adalah teknologi Augmented Reality (AR) yang memadukan antara 
kondisi nyata dengan benda-benda maya menjadi satu kesatuan. Augmented Reality akan mengubah cara kita memandang dunia atau setidaknya cara penggunanya melihat dunia. Seperti contoh, ketika Anda membaca brosur, dengan Augmented Reality brosur tersebut tidak hanya akan menampilkan tulisan dan foto secara $2 \mathrm{D}$, tetapi bisa melihat gambar dalam bentuk 3D yang terlihat seperti nyata. Sehingga Augmented Reality juga bisa digunakan sebagai salah satu media promosi yang efektif. Untuk itu pemanfaatan teknologi Augmented Reality sebagai sarana pengenalan ataupun promosi dirasakan perlu adanya. Melalui Augmented Reality yang dipasangkan pada smartphone android akan dapat menghasilkan objek 3D secara real-time di lingkungan nyata melalui kamera smartphone dan juga marker. Hal tersebut dapat menjadi opsi lain untuk lebih memperkenalkan jurusan yang terdapat di UNISKA, tata letak ruangan, serta bagian-bagian di gedung baru UNISKA.

Dalam penyusunan skripsi ini, penulis sedikit banyak terinspirasi dan mereferensi dari penelitianpenelitian sebelumnya yang berkaitan dengan latar belakang masalah pada skripsi ini. Berikut ini penelitian terdahulu yang berhubungan dengan skripsi ini antara lain: "Augmented Reality Book Pengenalan Gedung Universitas Pendidikan Ganesha", Ni Luh Nita Sari (2014). Penelitian "Penerapan Teknologi Augmented Reality Sebagai Media Pengenalan Gedung Baru Unikom Berbasis Android", Selvia Lorena br. Ginting (2016). Dan "Pengembangan Aplikasi Profil Sekolah Berbasis Augmented Reality Sebagai Media Informasi Profil Sekolah Di SMA Negeri 1 Wonogiri”, Ratnawati (2016).

Dari gambaran latar belakang yang dijelaskan maka peneliti berharap dapat membantu pihak UNISKA dalam memperkenalkan atau mempromosikan kampus mereka secara lebih efektif dan variatif.

\section{METODE PENELITIAN}

Dalam penelitian diperlukan data penelitian yang mendukung penyusunan penelitian ini. Berikut merupakan metode-metode yang digunakan untuk mendapatkan data:

1. Wawancara

Wawancara merupakan suatu metode yang diterapkan dengan cara wawancara langsung dengan pihak yang bersangkutan berkaitan dengan masalah yang dihadapi. Dengan metode ini data yang didapatkan memiliki tingkat keakuratan yang tinggi karena mengetahui informasi langsung dari sumbernya.

2. Observasi

Observasi yaitu sistematika dengan cara terjun langsung ke lapangan, dalam hal ini penulis langsung terjun ke lapangan guna mengambil data yang berhubungan dengan data yang diperlukan. Apalagi dalam penelitian ini sangat diperlukan pengamatan langsung ke lapangan guna mendapatkan informasi langsung mengenai pekerjaan para karyawan dan pemesan para pelanggan yang pernah memesan.

3. Kepustakaan

Untuk melengkapi data yang diperlukan untuk penelitian ini diperlukan juga data tambahan yang terdiri referensi dari buku-buku, artikel maupun data yang berada di internet guna mendukung kajian pustaka dalam membahas pokok masalah yang diteliti.

Setelah data berhasil dikumpulkan, maka penulis membuat aplikasi menggunakan metode Waterfall. Di mana kelebihan menggunakan metode air terjun (waterfall) adalah metode ini memungkinkan untuk departementalisasi dan kontrol. Proses pengembangan model fase one by one, sehingga meminimalis kesalahan yang mungkin akan terjadi. Pengembangan bergerak dari konsep, yaitu melalui desain, implementasi, pengujian, instalasi, penyelesaian masalah, dan berakhir di operasi dan pemeliharaan.

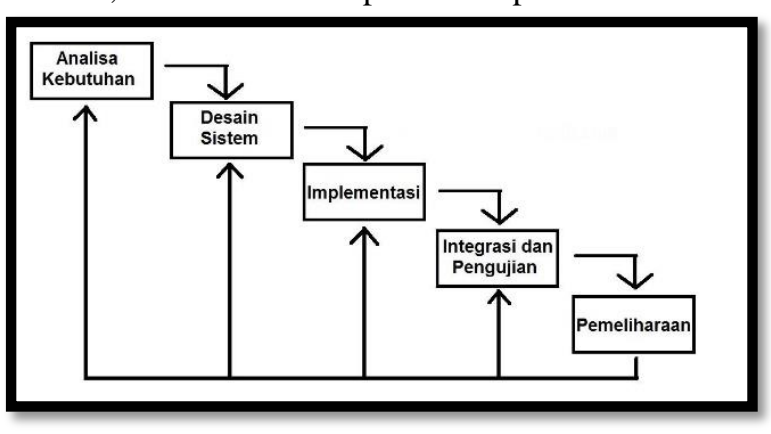

\section{Gambar 1. Metode Waterfall}

Tahapan-tahapan pembuatan sistem ini adalah sebagai berikut:

1. Requirement Analisys (Analisis Kebutuhan) Tahap ini pengembang sistem diperlukan komunikasi yang bertujuan untuk memahami perangkat lunak yang diharapkan oleh pengguna dan batasan perangkat lunak tersebut. Informasi ini biasanya dapat diperoleh melalui wawancara, diskusi atau survei langsung. Informasi dianalisis untuk mendapatkan data yang dibutuhkan oleh pengguna.

2. System Design (Desain Sistem)

Spesifikasi kebutuhan dari tahap sebelumnya akan dipelajari dalam fase ini dan desain sistem disiapkan. Desain Sistem membantu dalam menentukan perangkat keras (hardware) dan sistem persyaratan dan juga membantu dalam mendefinisikan arsitektur sistem secara keseluruhan.

3. Implementation (Implementasi)

Pada tahap ini, sistem pertama kali dikembangkan di program kecil yang disebut unit, yang terintegrasi dalam tahap selanjutnya. Setiap unit dikembangkan dan 
diuji untuk fungsionalitas yang disebut sebagai unit testing.

4. Integration \& Testing (Integrasi \& Pengujian)

Seluruh unit yang dikembangkan dalam tahap implementasi diintegrasikan ke dalam sistem setelah pengujian yang dilakukan masing-masing unit. Setelah integrasi seluruh sistem diuji untuk mengecek setiap kegagalan maupun kesalahan.

5. Operation \& Maintenance (Operasi \& Pemeliharaan)

Tahap akhir dalam model waterfall. Perangkat lunak yang sudah jadi, dijalankan serta dilakukan pemeliharaan. Pemeliharaan termasuk dalam memperbaiki kesalahan yang tidak ditemukan pada langkah sebelumnya. Perbaikan implementasi unit sistem dan peningkatan jasa sistem sebagai kebutuhan baru.

\section{HASIL DAN PEMBAHASAN}

Pada tahap ini akan diuraikan hasil dan pembahasan dari hasil penelitian bagaimana tampilan aplikasi dan hasil tampilan objek 3 dimensi kampus UNISKA Banjarmasin.

1. Tampilan Splash Screen

Saat aplikasi pertama kali dibuka, layer akan berorientasi landscape ke kiri dan menampilkan splash screen berupa logo UNISKA.

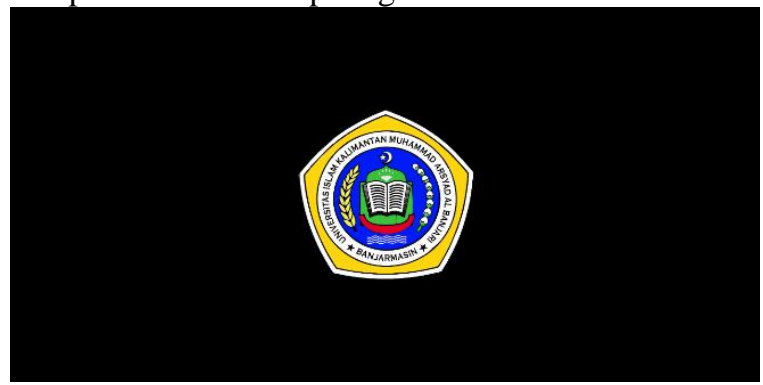

Gambar 1. Tampilan Splash Screen

2. Tampilan Loading

Setelah splash screen selesai maka akan muncul halaman loading yang berupa logo aplikasi.

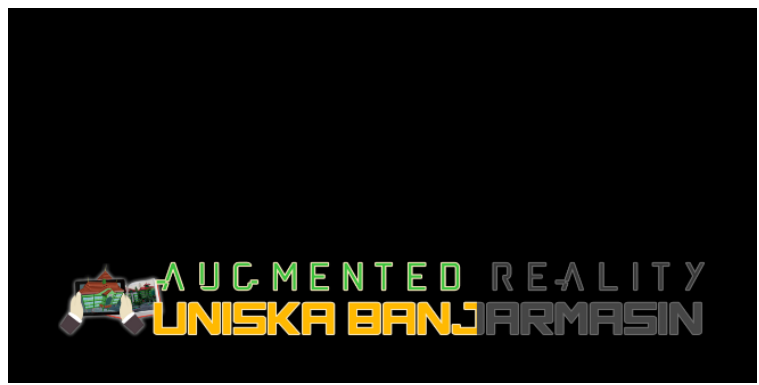

Gambar 2. Tampilan Loading
3. Tampilan Menu Utama

Pada menu utama terdapat 6 pilihan menu yaitu menu Mulai Mode AR, Jelajah UNISKA, Informasi, Petunjuk Penggunaan, Tentang dan Keluar.

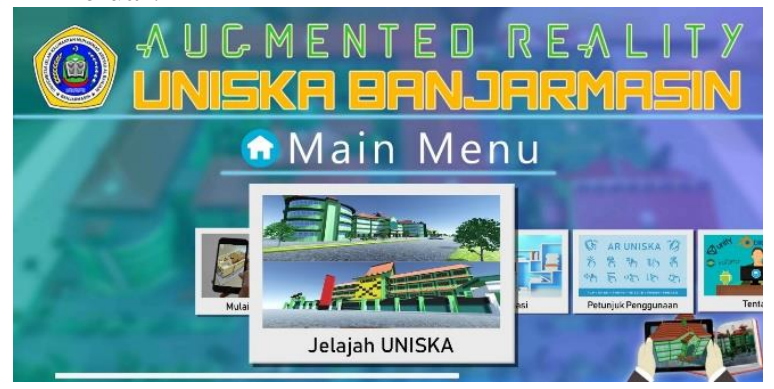

Gambar 3. Tampilan Menu Utama

4. Tampilan Menu Mode AR

Terdapat 2 gedung yang dapat dilihat dalam Mode AR ini, yaitu rancangan gedung baru UNISKA dan gedung utama UNISKA.

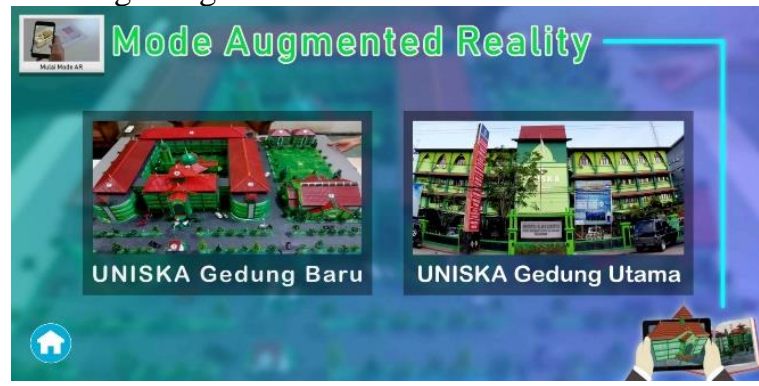

Gambar 4. Tampilan Menu Mode AR

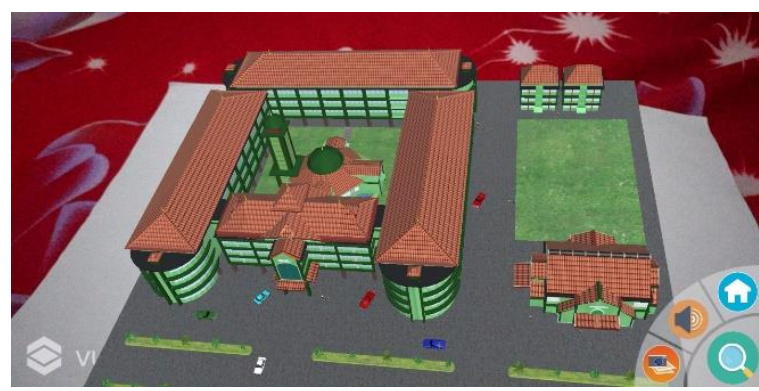

Gambar 5. Tampilan Mode AR Gedung Baru UNISKA

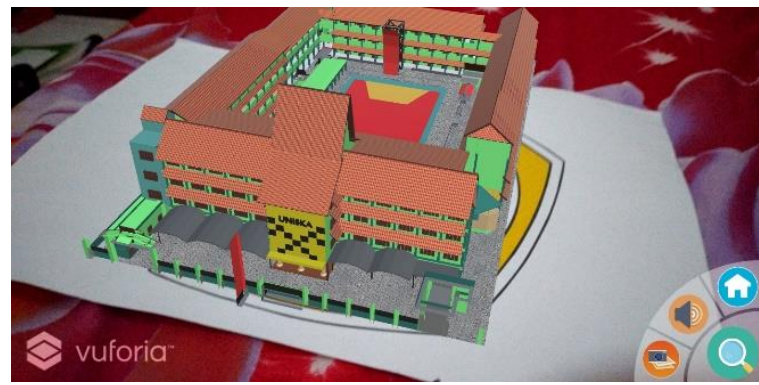

Gambar 6. Tampilan Mode AR Gedung Utama UNISKA

5. Tampilan Menu Pencarian

Menu pencarian terdapat pada saat Mode AR aktif. Pada menu pencarian ini terdapat 9 
bangunan atau tempat yang bisa dicari pada gedung baru UNISKA, yaitu: gedung rektorat, masjid, gedung fakultas, ruang kuliah, gedung serba guna, asrama mahasiswa, lapangan olahraga, pos jaga.

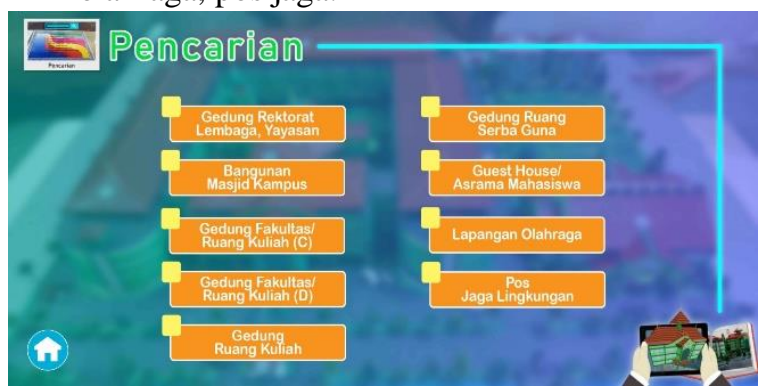

Gambar 7. Tampilan Menu Pencarian Gedung Baru

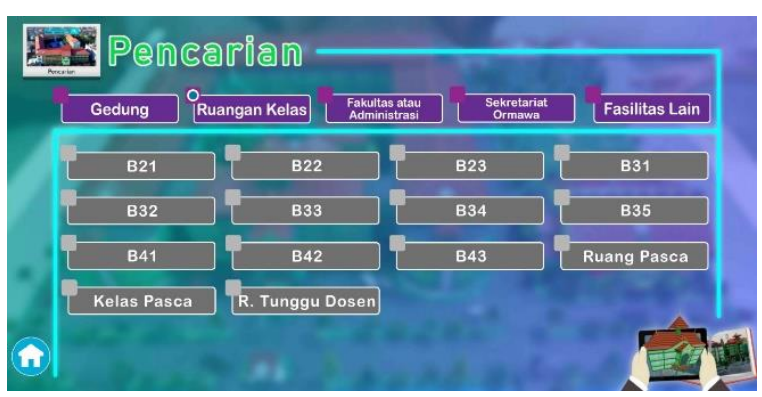

Gambar 8. Tampilan Menu Pencarian Gedung Utama

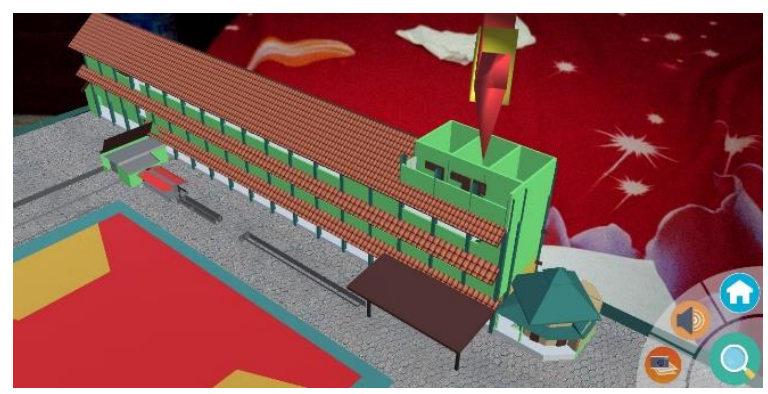

Gambar 9. Tampilan Mode AR Pencarian Gedung/Ruangan

6. Tampilan Menu Jelajah UNISKA

Terdapat 2 gedung yang dapat kita jelajahi pada menu ini, yaitu rancangan gedung baru UNISKA dan gedung utama UNISKA.

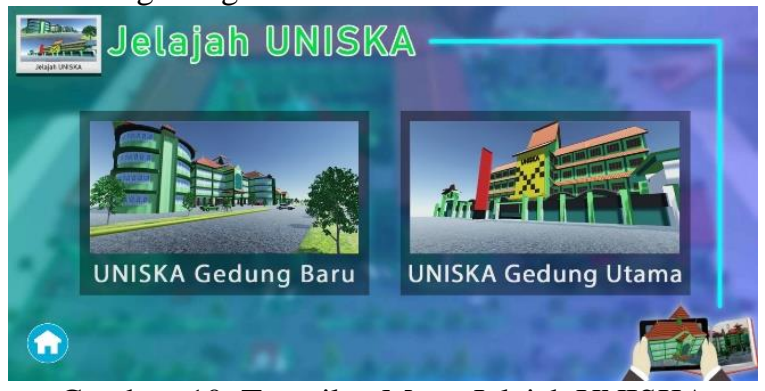

Gambar 10. Tampilan Menu Jelajah UNISKA

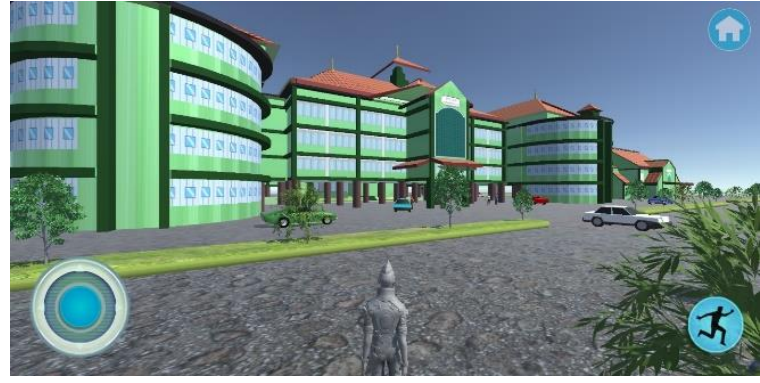

Gambar 11. Tampilan Jelajah UNISKA Gedung Baru

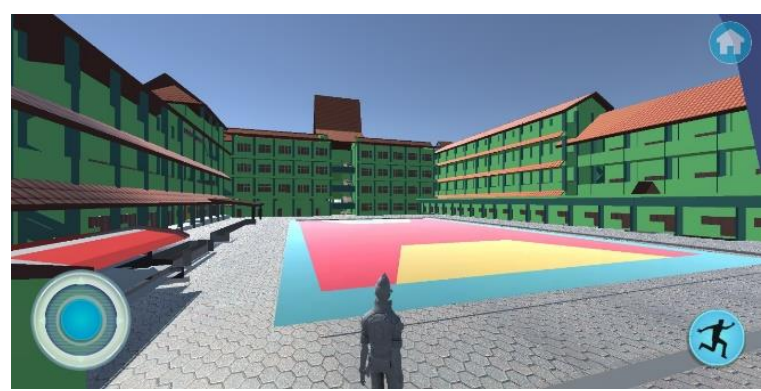

Gambar 12. Tampilan Jelajah UNISKA Gedung Utama

7. Tampilan Menu Informasi

Pada menu informasi ini terdapat 3 informasi yang dapat pengguna lihat, yaitu: UNISKA, Fakultas, dan Unit Kegiatan Mahasiswa (UKM).

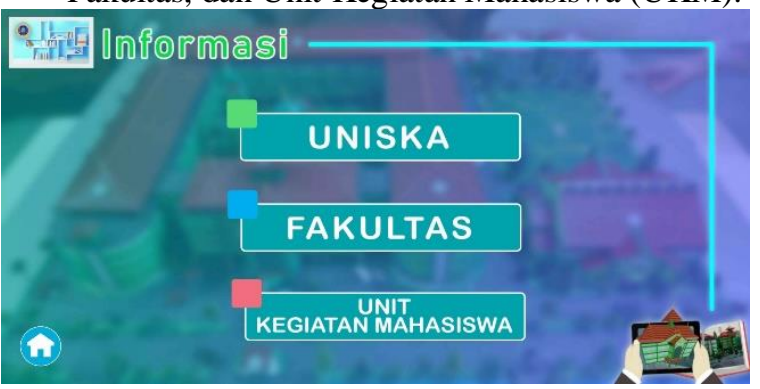

Gambar 13. Tampilan Menu Informasi

8. Tampilan Menu UNISKA

Pada menu ini terdapat 3 informasi tentang UNISKA yang dapat dilihat pengguna, yaitu: profil, visi dan misi, dan sejarah.

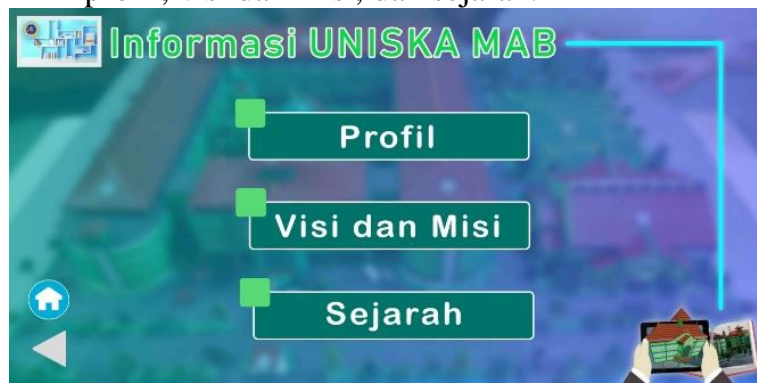

Gambar 14. Tampilan Menu Informasi UNISKA 
9. Tampilan Menu Fakultas

Pada menu ini terdapat 10 fakultas atau program yang dapat dilihat informasinya, yaitu: Fakultas Teknologi Informasi, Fakultas Teknik, Fakultas Ilmu Sosial dan Ilmu Politik, Fakultas Keguruan dan Ilmu Pendidikan, Fakultas Ekonomi, Fakultas Pertanian, Fakultas Studi Islam, Fakultas Kesehatan Masyarakat, Fakultas Hukum, Pasca Sarjana.

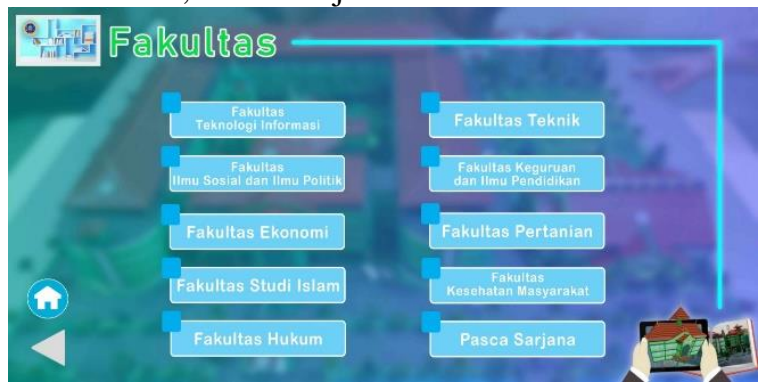

Gambar 15. Tampilan Menu Fakultas

10. Tampilan Menu Unit Kegiatan Mahasiswa Pada menu ini terdapat 11 UKM yang dapat dilihat informasinya, yaitu: Band, Lembaga Pers Mahasiswa, Paduan Suara UNISKA, Kajian Dakwah Kampus, Mahasiswa Pecinta Alam, Sport, Koperasi Mahasiswa, Resimen Mahasiswa, Sanggar Titian Barantai, Korps Suka Rela, Praja Muda Karana.

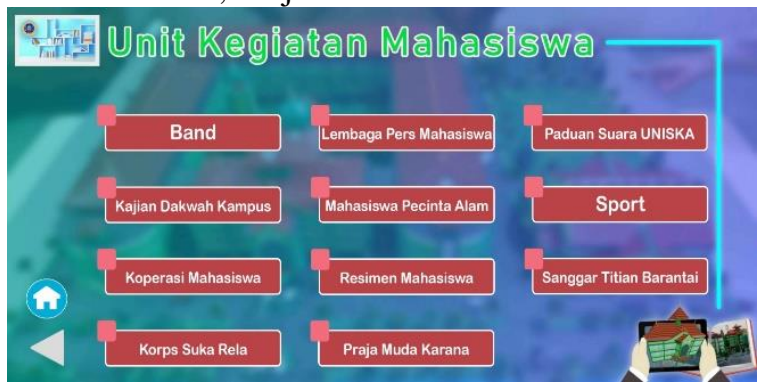

Gambar 16. Tampilan Menu Unit Kegiatan Mahasiswa

11. Tampilan Petunjuk Penggunaan

Berisi informasi tentang bagaimana cara menggunakan aplikasi ini.

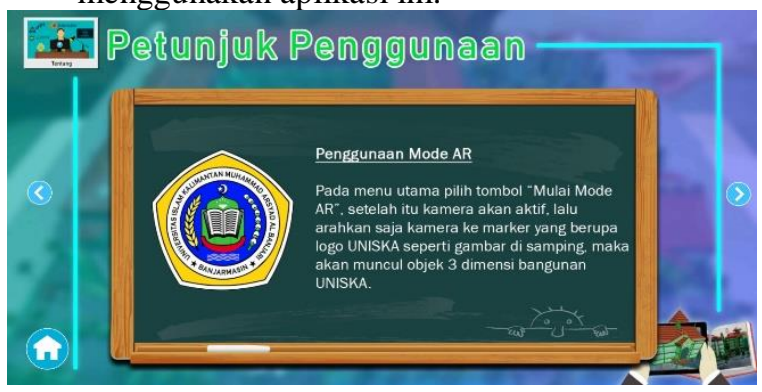

Gambar 17. Tampilan Informasi Petunjuk Penggunaan
12. Tampilan Informasi Tentang

Berisi informasi tentang aplikasi dan pembuat aplikasi ini.

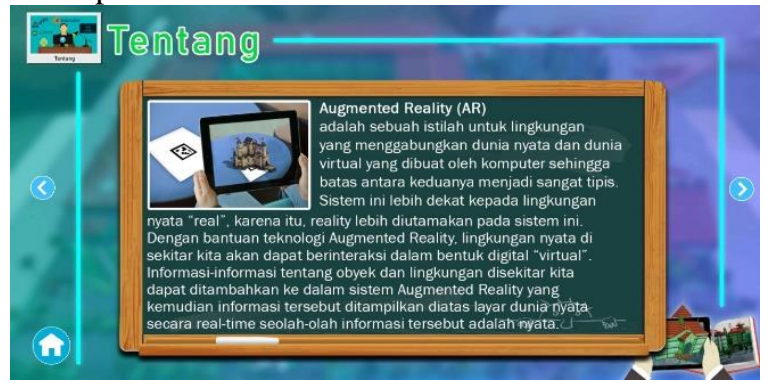

Gambar 18. Tampilan Informasi Tentang

\section{PENUTUP}

\section{Kesimpulan}

Berdasarkan hasil dari penelitian yang telah dilakukan dapat ditarik kesimpulan sebagai berikut :

1. Dengan adanya aplikasi ini akan membantu calon mahasiswa atau mahasiswa baru untuk dapat mengenal pemetaan kampus UNISKA MAB dengan lebih baik beserta rancangan gedung barunya.

2. Dari hasil pengujian tracking marker untuk menampilkan objek berdasarkan jarak kamera ke marker dan sudut pengambilan dapat ditarik kesimpulan bahwa jarak ideal kamera dengan marker ialah antara 10 centimeter sampai dengan 20 centimeter serta dengan sudut pengambilan $30^{\circ}-90^{\circ}$. Sedangkan untuk sudut $90^{\circ}$ memiliki jarak pengambilan terjauh antara 10 centimeter sampai 60 centimeter.

3. Aplikasi ini bisa dijalankan dalam keadaan offline.

\section{Saran}

Demi pengembangan aplikasi ini agar menjadi lebih baik lagi untuk penggunaannya penulis menyampaikan saran sebagai berikut :

1. Setelah gedung baru UNISKA sudah selesai dikerjakan, ke depannya diperlukan pemetaan denah yang lebih detail karena pemodelan 3D kampus pada aplikasi ini hanya sebatas eksterior sehingga pengguna tidak bisa mengetahui detail dari interior ruangan.

2. Aplikasi hanya bisa berjalan hanya pada smartphone yang menggunakan sistem operasi android, ke depannya diperlukan aplikasi yang dapat berjalan di semua sistem operasi pada smartphone. 


\section{REFERENSI}

Aditya, R. (2018). Pengenalan Ikan Cupang (Betta Fish) Menggunakan Augmented Reality. Tugas Akhir Skripsi, 1-76.

Dictio. (2018, February 2). Apa yang dimaksud dengan Diagram aktivitas atau Activity Diagram ? Retrieved from https://www.dictio.id: https://www.dictio.id/t/apa-yang-dimaksuddengan-diagram-aktivitas-atau-activitydiagram/15129

Efendi, I. (n.d.). Pengertian Augmented Reality(AR). Retrieved from https://www.it-jurnal.com: https://www.it-jurnal.com/pengertianaugmented-realityar/

kursusprivat. (2019, March 28). Pemodelan 3 Dimensi (3D Modeling). Retrieved from http://www.kursusprivat.com/: http://www.kursusprivat.com/artikel/artikel.p hp?id=13\&judul=Pemodelan-3-Dimensi(3D-Modeling)

Mengenal Lebih Dekat Tentang Unity3D, Game Engine Pembuat Game 3D. (2017, July 1). Retrieved from https://idcloudhost.com: https://idcloudhost.com/mengenal-lebihdekat-tentang-unity3d-game-enginepembuat-game-3d/

Ni Luh Nita Sari, P. N. (2014). Augmented Reality Book Pengenalan Gedung Universitas Pendidikan Ganesha. Kumpulan Artikel Mahasiswa Pendidikan Teknik Inforrmatika, 353-363.

Nugroho, A. (2017). Pengenalan Denah Kampus Uniska Banjarmasin Untuk Mahasiswa Baru Menggunakan Teknologi Augmented Reality. Tugas Akhir Skripsi, 1-90.

Pendidikan, D. (2019, February 02). Kecerdasan Buatan ( Artificial Intelegence ) Pengertian \& Menurut Para Ahli Serta ( Tujuan Kelebihan - Kerugian - Contoh ). Retrieved from https://www.dosenpendidikan.com: https://www.dosenpendidikan.com/kecerdasa n-buatan-artificial-intelegence-pengertianmenurut-para-ahli-serta-tujuan-kelebihankerugian-contoh/
Putra, A. W. (2015, April 30). Vuforia - SDK Canggih Untuk Wujudkan Aplikasi dan Game Dengan Teknologi Augmented Reality. Retrieved from https://teknojurnal.com: https://teknojurnal.com/vuforia/

Ratnawati. (2016). Pengembangan Aplikasi Profil Sekolah Berbasis Augmented Reality Sebagai Media Informasi Profil Sekolah Di Sma Negeri 1 Wonogiri. TUGAS AKHIR SKRIPSI, 1-175.

Selvia Lorena Br. Ginting, E. S. (n.d.). Penerapan Teknologi Augmented Reality Sebagai Media Pengenalan Gedung Baru Unikom Berbasis Android. Majalah Ilmiah UNIKOM, 283-296.

Subrata, E. H. (n.d.). Apa itu Computer Vision? Ini Penjelasan Lengkapnya. Retrieved from https://dosenit.com: https://dosenit.com/ilmukomputer/komputer-dasar/apa-itu-computervision 